\title{
The Profile of Peer-Assessment Applied Students in Learning Mathematics Based on Self-Confidence
}

\author{
Putra Aji Almujtahid \\ Mathematics Education Department \\ of Graduate Program \\ Sebelas Maret University (UNS) \\ Surakarta, Indonesia \\ almujtahid@student.uns.ac.id
}

\author{
Hasih Pratiwi \\ Mathematics Education Department \\ of Graduate Program \\ Sebelas Maret University (UNS) \\ Surakarta, Indonesia \\ hasihpratiwi@gmail.com
}

\author{
Mardiyana \\ Mathematics Education Department \\ of Graduate Program \\ Sebelas Maret University (UNS) \\ Surakarta, Indonesia \\ mardiyana@staff.uns.ac.id
}

\begin{abstract}
Peer-assessment is one of assessment for learning that able to enhance understanding in learning mathematics by take and give feedback within the process of learning. Peerassessment will occur when students are active to give ideas, suggestions and critics as feedback. Self-confidence is important factor in the process of take and give feedback. This study aims to determine the profile of peer-assessment applied students in learning mathematics based on self-confidence in SMP Negeri 1 Playen, Gunung Kidul. This research is a qualitative research with questionnaire, observation and interview methods. The outcomes showed that the high self-confidence student has characteristics: 1) capable giving feedback, 2) responsible for own learning, 3) takes feedback to enhance mathematics understanding. The medium self-confidence student has characteristics: 1) able giving feedback, 2) responsible for own learning, 3) takes feedback to enhance mathematics understanding. Low self-confidence student has characteristics: 1) unable giving feedback, 2) do not responsible for own learning, 3) do not take feedback to enhance mathematics understanding.
\end{abstract}

Keywords-peer-assessment; self-confidence; learning mathematics

\section{INTRODUCTION}

Assessment in Indonesian education emphasis on assessment for learning. Assessment for learning is the process of seeking and interpreting evidence for use by learners and their teachers to decide where the learners are in their learning, where they need to go and how best to get there [1]. Evidence is used as feedback such as ideas, suggestions and critics. The learner learns to learning within the learning process by using feedback from this assessment.

In higher education settings, assessment tasks get the attention of students, but once students submit their work they typically become disengaged with the assessment process. Hence, opportunities for learning are lost as they become passive recipients of assessment outcomes [2]. Peer-assessment is one of alternative solution for this problem. The outcome of this assessment or feedback that given from peers helps them to determine the learners are in their learning, where they need to go and how best to get there.

Both assessors and assesses will gain benefits by improving their qualifications during the procedures of peer-assessment, some students often doubt on peers' qualifications and knowledge of assessment, then more studies need to be carried out on students' attitudes and perceptions about peer-assessment [3]. Students' attitudes and perceptions about peer-assessment need to be studied more in-depth so that the peer assessment process works effectively.

Mathematical anxiety, lack of interest and negative feeling towards mathematics, it makes difficult learning mathematics [4]. It makes peer assessment ineffective, because it makes them unwilling to give feedback. Feedback is the essence of peer assessment. One of the student attitudes that encounter them is self-confidence, and then it needs to be studied about the profile of peer-assessment applied students in learning mathematics based on self-confidence.

\section{THEORETICAL BACKGROUND}

\section{A. Peer-assessment}

Peer-assessment is one of assessment for learning or formative assessment. The term 'assessment' refers to all the those activities undertaken by teachers, and by their students in assessing themselves, which provide information to be used as feedback for the modification of teaching and learning activities in which they are engaged [5]. This assessment emphasizes providing feedback as information to improve the learning of mathematics, not scoring on their work. This assessment prefers students learn math by using the results of feedback given by his peers to be corrected them and reassured their understanding, especially in mathematics.

Peer-assessment includes processes which require students to provide either feedback or grades (or both) to their peers on a product, process, or performance, based on the criteria of excellence for that product or event which students may have been involved in determining [2]. This assessment is not just receiving feedback from peers only, but also can provide feedback to his peer. This process can strengthen the learning process of mathematics known to be difficult.

Students were able to avoid common sources of error and hence improve their performance as measured by a coupled pretest and post-test after peer-assessment. Peer-assessment has been found to provide the greatest boost to those of intermediate 
mathematical ability. Students of lower mathematical ability would benefit from direct instruction in simple mathematical skills to allow them to benefit from participation in this activity [6]. Students will not repeat the same mistakes again as long as they can receive feedback as a source for learning math.

The study revealed that participants are confident in their ability to assess peers' work. They confirmed that following clear rubrics helped them understand the evaluation criteria and supported them in providing peers with detailed feedback [7]. Clear rubrics are essential in assisting during peer assessment so that students can give each other feedback more detail.

\section{B. Self-confidence}

Self-confidence refers to a person's perceived ability to tackle situations successfully without learning of others and to have a positive self-evaluation. A self-confident person perceives himself to be socially competent, emotionally mature, intellectual, adequate, successful, satisfied, decisive, optimistic, independent, self-reliant, self-assured, forward moving, fairly assertive and having leadership qualities [8]. Self-confidence helps students deal with all the problems encountered, including in the face of the results of peer feedback.

The more self confident learners were, the higher were their scores on the test. Highly self-confident learners were ready to try to speak in front of others. Lack of general self-confidence, on the other hand, resulted in lack of interest to strive for high quality oral performance. Less confident learners were not certain of their abilities. They tended to try less which in turn led to low levels of achievement [9]. Self-confidence is very important in the success of the peer-assessment process in the take and give feedback.

Reference [10] classify characteristics of individuals who have a proportional self-confidence are

1) Believing in the ability or self-competence, does not require the praise, recognition, acceptance, or respect of others.

2) Not encouraged to show conformist attitude to be accepted by others or groups.

3) Dare to accept and face the rejection of others, dare to be yourself.

4) Have good self-control

5) It has an internal locus of control (see success or failure, depends on the business itself and does not easily give up to fate or circumstances and does not depend on or expect the help of others).

6) Have a positive outlook on yourself, others and outside situations.

7) Have a realistic expectation of yourself.

Indicators of students have confidence in this research is believing in self-ability, acting independently in making decisions, having a positive sense of self, and dare to express opinions.

\section{METHODS}

This research is a qualitative research using case-study strategy that aims to determine the profile of peer-assessment applied students in learning mathematics based on selfconfidence in SMP Negeri 1 Playen, Gunung Kidul.

\section{A. Participants}

The subjects of this research are three students that have different self-confidences in SMP Negeri 1 Playen. Samples are taken by using purposive sampling technic. Self-confidence's samples are divided into three categories, there are high selfconfidence, medium self-confidence, and low self-confidence.

\section{B. Data Collection}

Methods of data collection use questionnaire, observation and interview methods. Self-confidence questionnaire uses indicators as in believing in self-ability, acting independently in making decisions, having a positive sense of self, and dare to express opinions.

Each indicator consists of 6 statements, supporting statements and unsupporting statements. Total questions are 24 from four indicators. Questions during the interview toward students are

1) Are students able to give feedback to their peer?

2) Are students responsible for their own learning?

3) Does the student require feedback to enhance their mathematics understanding?

These questions are used in the interview in order to verify about students doing when applying peer assessment during observation.

\section{RESUlT AND DISCUSSION}

\section{A. High Self-Confidence Subject}

Subject belonging to the category of high self-confidence are able to provide their feedback in detail, not just giving value. The subject also gives corrections to mistakes made peer either mistakenly written or concepts, and provide a correct answer record.

Subject who have high self-confidence have responsibility for their own work. Subject can receive suggestions from their friends and criticize when their friends are wrong in giving corrections to their work.

Subjects with high self-confidence can accept and improve their understanding of math through peer-assessment, ie the subject can answer the previously answered wrong to be true, and can reflect from the work of his friend. Subjects can be asked the same question orally.

\section{B. Medium Self-Confidence Subject}

Subject belonging to the category of medium self-confidence are able to provide feedback, but not too detailed. The subject also provides corrections to errors that his peer does know only, as well as providing correct answers. 
Subject who have medium self-confidence are having responsibility for their own work. Subject can accept suggestions from their friends or criticize if their friends are wrong in giving corrections to their work.

Subject with medium self-confidence are able to accept and improve their understanding of math through peer-assessment, ie the subject can answer the previously answered wrong to be true, and can reflect from the work of his friend.

\section{Low Self-Confidence Subject}

Subject belonging to the low self-confidence category can not afford to give their feedback, just giving value from their friend's work. The subject also does not provide corrections to errors made peernya and not provide the correct answer records.

Subject with low self-confidence have responsibility for their own work. Subject can accept suggestions from their friends or criticize if their friends are wrong in giving corrections to their work.

Subject with low self-confidence do not know the error in answering the questions after the peer-assessment, as well as the subject repeats his mistakes again.

\section{CONCLUSION}

Peer-assessment is one of assessment for learning that able to enhance understanding in the process of learning. Peerassessment allows students to reflect on both their own work and their peer work. The key students want to give feedback and want to receive it. One important factor in successful peerassessment is student's self-confidence. Students can give feedback is one of self-confidence's role. Self-confidence makes students brave to give their feedback.

The outcomes showed the profil such that

1) The high self-confidence student has the characteristics ie capable giving feedback, responsible for own learning, and takes feedback to enhance mathematics understanding.

2) The medium self-confidence student has characteristic ie capable giving feedback, responsible for own learning, and takes feedback to enhance mathematics understanding.
3) The low self-confidence student has characteristics ie unable giving feedback, do not responsible for own learning, and do not take feedback to enhance mathematics understanding.

\section{ACKNOWLEDGMENT}

We are grateful to all of support from Sebalas Maret University (UNS) especially to Dr. Mardiyana and Dr. Hasih Pratiwi for his valuable comments and feedback.

\section{REFERENCES}

[1] Budiyono, Pengantar Penilaian Hasil Belajar. UNS Press: Surakarta, 2016, pp. 158.

[2] G. Thomas, D. Martin, and K. Pleasants, "Using self- and peer-assessment to enhance students; future-learning in higher education," Journal of University Teaching \& Learning Practice, 8(1), 2011.

[3] A. Karami and A. Rezaei, "An overview of peer-assessment: the benefits and importance,"Journal fot the Study of English Linguistics, Macrothink Institute, Vol. 3 No.1, 2015, pp. 93-100.

[4] B. Raj Acharya, "Factors Affecting Difficulties in Learning Mathematics," Mathematics Learners International Journal of Elementary Education. Vol. 6, No. 2, 2017, pp. 8-15.

[5] A. R. Nwabude, "Using a VLE to Enhance 'Assessment for Learning' Mathematics in School Scector," International Journal of Managing Information Technology, Vol. 3, Issue 3, 2011, pp. 93-103.

[6] F. J. Scott, "A Simulated Peer-Assessment Approach to Improving Student Performance in Chemical Calculations," Chemistry Education Research and Practice, Vol.1, No.1, 2013, pp. 1-3.

[7] A.M.F. Yousef, U. Schroeder, and M. Wosnitza, "The Effect of Peer Assessment Rubrics on Learners' Satisfaction and Performance within a Blended MOOC Environment," 7th International Conference on Computer Supportted Education , 2015, pp. 148-159.

[8] M. Goel and P. Aggarwal, "A Comparative Study of Self Confidencs of Single Child and Child with Sibling," International Journal of Research in Social Sciences, Vol. 2, Issue 3, 2012, pp. 89-98.

[9] S. M. Al-Hebaish, "The correlation between general self-confidence and academic achievement in the oral presentation course," Theory and Practice in Language Studies. Finland, vol. 2, No.1, 2012, pp. 60-65,

[10] E. Fatimah,. Psikologi Perkembangan : Perkembangan Peserta Didik. Pustaka Setia: Bandung, 2006, pp. 149-159. 